\title{
OCENA ZASADNOŚCI UCZESTNICTWA W WYSTAWACH ŚWIATOWYCH (W KONTEKŚCIE AKTYWNOŚCI WYSTAWIENNICZEJ POLSKI PODCZAS EXPO 2010 W SZANGHAJU)
}

\begin{abstract}
Współcześnie co pięć lat odbywają się powszechne wystawy światowe (nazywane również Expo), podczas których prezentują się niemal wszystkie kraje oraz kilkadziesiąt organizacji międzynarodowych. Udział w takich wydarzeniach - poprzez demonstrację dorobku kulturalnego, naukowego i technicznego - ma się przyczynić przede wszystkim do wykreowania pożądanej marki narodowej, a w efekcie między innymi do stymulowania ruchu turystycznego, jak również nawiązania kontaktów gospodarczych. Jednak udział w trwających przez pół roku Expo jest dużym wyzwaniem organizacyjnym oraz generuje spore wydatki z państwowych budżetów. Ponadto rozwój internetu sprawił, że obecnie miliardy osób (w tym również turystów i inwestorów) mają łatwy dostęp do informacji o poszczególnych krajach oraz ich ofertach. W związku z tym można podać w wątpliwość sens organizowania w XXI w. tak dużych wydarzeń (określanych również jako megawydarzenia), jakimi są wystawy światowe. Można postawić tezę, że ich niegdyś prymarna funkcja informacyjnoedukacyjna, którą pełniły w okresie ostatnich 150 lat, ma obecnie marginalne znaczenie. W związku z tym celem artykułu jest ocena zasadności wystawiania się podczas wystaw światowych. Aby tego dokonać, zestawiono argumenty przemawiające za uczestniczeniem w takich wydarzeniach (m.in. okazja do zapoznania się wystapieniami wielu krajów w jednym miejscu, prezentacja ofert narodowych z zaangażowaniem wszystkim zmysłów zwiedzających), jak również kontrargumenty (m.in. wysokie koszty udziału, zanikanie konkursowego charakteru wystawy, trudności z określeniem uzyskiwanych efektów wizerunkowych). Wnioski autora wynikają z kilkunastoletniego śledzenia rynku targów i wystaw gospodarczych, a także z obserwacji poczynionych podczas Expo 2010, które odbyło się w Szanghaju i było największym wydarzeniem wystawienniczym w historii.

Słowa kluczowe: wystawy światowe, Expo 2010, marketing wystawienniczy, wizerunek kraju
\end{abstract}

\section{WSTĘP}

Historia wystawiennictwa nierozerwalnie wiąże się z wielkimi wystawami światowymi. Zorganizowanie pierwszej $\mathrm{z}$ nich w połowie XIX w. było następstwem rewolucji przemysłowej oraz głębokich zmian, jakie dokonały się w sposobach produkcji. Na przestrzeni kolejnych dekad wydarzenia prezentujące dorobek państw oraz organizacji międzynarodowych przekształciły swoją formułę, rozszerzając swój zakres i dostosowując się do zmieniających się warunków społeczno-gospodarczych. Obecnie wobec wzrastającej mobilności ludności oraz szybkiego rozwoju elektronicznych form komunikacji należy się zastanowić, czy zasadne jest uczestniczenie w wystawach świato-

\footnotetext{
${ }^{1}$ Dr Marcin Gębarowski, Katedra Marketingu, Wydział Zarządzania, Politechnika Rzeszowska, Al. Powstańców Warszawy 8, 35-959 Rzeszów, tel.: + 48 (17) 86514 74, e-mail: marcing@ @rz.edu.pl
} 
wych. Organizowanie ekspozycji narodowych przynosi korzyści wizerunkowe poszczególnym krajom, jednak wiąże się $\mathrm{z}$ wielomiesięcznym zaangażowaniem wielu osób oraz wydawaniem znacznych kwot, pochodzących głównie z środków publicznych. W tym kontekście celem artykułu jest dokonanie oceny zasadności uczestniczenia w wystawach światowych w charakterze wystawców (ze szczególnym uwzględnieniem wystawy Expo 2010, która odbyła się w Szanghaju).

\section{ROZWÓJ WYSTAW ŚWIATOWYCH}

Historię organizowania wystaw światowych rozpoczęła Wielka Wystawa Przemysłu Wszystkich Narodów, która odbyła się w dobie wiktoriańskiej Anglii. Zorganizowano ją w londyńskim Hyde Parku w 1851 r. Od tego momentu co kilka lat prezentowano w różnych krajach ekspozycje poświęcone przeglądowi światowych osiągnięć. Nazywano je wystawami powszechnymi lub uniwersalnymi, wzywając do uczestniczenia w nich wszystkie państwa oraz pokazując całość działalności wytwórczej i twórczej. Takie wystawy organizowano dość regularnie, najczęściej w Europie i tu miały one swój najbardziej zgodny z założeniami wyraz. Na wystawie królowały zdobycze przemysłu - wyroby oraz rozwój technologii i techniki pozwalający na coraz bardziej masową produkcję. Prezentowano rzemiosło, od wyrobów prostych, od rękodzielnictwa najbardziej tradycyjnego, do takich, które przedstawiały najwyższy poziom artystyczny i stopień luksusu. Wystawy obejmowały też sztukę - chociaż w $1851 \mathrm{r}$. w ograniczonym zakresie ${ }^{2}$.

Duże zainteresowanie wystawami powszechnymi sprawiało, że przygotowywano je chaotycznie (co zamiast zysków często przynosiło straty). W celu wprowadzenia jednolitych zasad organizowania takich przedsięwzięć wystawienniczych w 1928 r. utworzono w Paryżu Międzynarodowe Biuro Wystaw (BIE, Bureau International des Expositions), które rozpoczęło swoją działalność trzy lata później ${ }^{3}$. Jednak jeszcze 1928 r. przedstawiciele 31 państw podpisali porozumienie (wielokrotnie później modyfikowane) kodyfikujące reguły urządzania wystaw światowych oraz oddzielnie targów międzynarodowych. Zaproponowano również i przyjęto podział wystaw na światowe (powszechne, uniwersalne) oraz specjalistyczne (tematyczne) ${ }^{4}$. Wystawy powszechne są większe i cieszą się większym zainteresowaniem niż wydarzenia tematyczne. Od 1958 r. wystawy światowe zaczęto określać skrótem „Expo” wraz z dodaniem roku.

Ze względu na swój rozmach, wpływ na lokalną gospodarkę, wywoływany rozgłos medialny oraz frekwencję zwiedzających współczesne Expo uważane są przez wielu autorów zajmujących się tematyką targów i wystaw gospodarczych za kulturalny i gospodarczy odpowiednik igrzysk olimpijskich ${ }^{5}$. Tak duże przedsięwzięcia, jakimi są zarówno

\footnotetext{
2 A.M. Drexlerowa, A.K. Olszewski, Polska i Polacy na powszechnych wystawach światowych 1851-2000, Instytut Sztuki PAN, Warszawa 2005, s. 9-10.

${ }^{3}$ Szczegółowe informacje na temat powstania oraz działalności Międzynarodowego Biura Wystaw znajdują się na stronie internetowej: http://www.bie-paris.org. Szczegółowa historia wystaw światowych dostępna jest także pod adresem: http://www.expomuseum.com.

${ }^{4}$ Obecnie BIE zrzesza 168 państw i patronuje wystawom uniwersalnym oraz tematycznym. Pierwsze z nich organizowane są co pięć lat i trwają do pół roku. Wydarzenia specjalistyczne są mniejsze oraz bardziej jednorodne tematycznie. W ich wypadku ekspozycje prezentowane są przez trzy miesiące.

${ }^{5}$ P. Locker, Exhibition Design, AVA Publishing, Lausanne 2011, s. 13.
} 
olimpiady, jak i współczesne Expo, określa się w literaturze przedmiotu jako megawydarzenia (mega-events) ${ }^{6}$.

Na przestrzeni ponad półtora wieku odbyło się 70 wystaw o różnym znaczeniu i charakterze. Ponad 30 z nich miało status wystaw uniwersalnych (tab. 1).

Tabela 1. Lista powszechnych wystaw światowych (rok, miasto, kraj)

\section{Przed powołaniem Bureau International des Expositions (BIE)}

\begin{tabular}{|c|c|c|}
\hline 1851 Londyn - Wielka Brytania & 1888 Barcelona - Hiszpania & 1910 Bruksela - Belgia \\
\hline 1855 Paryż - Francja & 1889 Paryż - Francja & 1911 Turyn -Włochy \\
\hline 1862 Londyn - Wielka Brytania & $\begin{array}{l}1893 \text { Chicago - Stany Zjedno- } \\
\text { czone }\end{array}$ & 1913 Gandawa - Belgia \\
\hline 1867 Paryż - Francja & 1897 Bruksela - Belgia & $\begin{array}{l}1915 \text { San Francisco - Stany } \\
\text { Zjednoczone }\end{array}$ \\
\hline 1873 Wiedeń - Austria & 1900 Paryż - Francja & 1929 Barcelona - Hiszpania \\
\hline $\begin{array}{l}1876 \text { Filadelfia - Stany Zjedno- } \\
\text { czone }\end{array}$ & $\begin{array}{l}1904 \text { Saint Luis - Stany Zjed- } \\
\text { noczone }\end{array}$ & $\begin{array}{l}1933 \text { Chicago - Stany Zjed- } \\
\text { noczone }\end{array}$ \\
\hline 1878 Paryż - Francja & 1905 Liège - Belgia & \\
\hline 1880 Melbourne - Australia & 1906 Mediolan - Włochy & \\
\hline \multicolumn{3}{|c|}{ Po utworzeniu Bureau International des Exposition (BIE) } \\
\hline 1935 Bruksela - Belgia & $\begin{array}{l}1962 \text { Seattle - Stany Zjedno- } \\
\text { czone }\end{array}$ & 2010 Szanghaj - Chiny \\
\hline 1937 Paryż - Francja & 1967 Montreal - Kanada & 2015 Mediolan - Włochy \\
\hline $\begin{array}{l}1939 \text { Nowy Jork - Stany Zjed- } \\
\text { noczone }\end{array}$ & 1970 Osaka - Japonia & \multirow{2}{*}{$\begin{array}{c}2020 \text { Dubaj - Zjednoczone } \\
\text { Emiraty Arabskie }\end{array}$} \\
\hline 1949 Port-au-Prince - Haiti & 1992 Sewilla - Hiszpania & \\
\hline 1958 Bruksela - Belgia & 2000 Hanower - Niemcy & \\
\hline
\end{tabular}

Źródło: Opracowanie własne na podstawie: World Expos, http://www.bieparis.org/site/en/expos/about-expos/expo-categories/world-expos (dostęp: 12.09.2014).

Wraz z organizacją kolejnych edycji zmieniało się znaczenie wystaw światowych. Uogólniając, można założyć, że w wyszczególnionych okresach przyjmowały one następujący charakter ${ }^{7}$ :

- 1851-1889 - demonstrowanie potencjału produkcyjnego przemysłu i narodów;

- 1893-1939 - podkreślanie statusu poszczególnych krajów oraz dominującej w nich ideologii;

- 1945-1992 - dostarczanie wysublimowanej rozrywki oraz głębokich przeżyć;

- od 2000 r. - nowy rodzaj Expo, informowanie o negatywnych zjawiskach występujących w skali globalnej i zwracanie uwagi na zrównoważony rozwój.

\footnotetext{
${ }^{6}$ Por. między innymi M. Roche, Mega-events and Modernity: Olympics and Expos in the Growth of Global Culture, Routledge, London 2000; W.M. Dornscheidt, C. Groth, H.W. Reinhard, Mega-events, [w:] Trade Show Management, red. M. Kirchgeorg, W.M. Dornscheidt, W. Giese, N. Stoeck, Gabler, Wiesbaden 2005, s. 904; Y. Deng, S.W. Poon, Expo 2010 Shanghai China: a signature chapter of the Huangpu Riverfronts Trilogy, ,Journal of Place Management and Development” 5/2 (2012), s. 174-191.

${ }^{7}$ Por. W.M. Dornscheidt, C. Groth, H.W. Reinhard, op. cit., s. 906-908.
} 
O randze poszczególnych wystaw światowych decydowały przede wszystkim: liczba prezentujących się krajów, frekwencja zwiedzających oraz zajmowana powierzchnia. W Londynie w 1851 r. obecnych było 28 krajów, cztery lata później w Paryżu - 12, w Chicago w 1893 r. - 50, w Montrealu w 1967 r. - 62, w Osace w 1970 r. - 70, w Lizbonie w 1998 r. - 155. W Hanowerze w 2000 r. prezentowało się 189 państw i organizacji międzynarodowych, a podczas wystawy w japońskim Aichi w 2005 r. zwiedzający mogli zobaczyć 121 ekspozycji. Z kolei w Szanghaju w 2010 roku wystawców było blisko 250. Na pierwszej wystawie w Londynie pojawiło się $6 \mathrm{mln}$ osób, natomiast paryska ekspozycja z przełomu wieków przyciagnęła już ponad $48 \mathrm{mln}$ zwiedzających. Podobne zainteresowanie udało się uzyskać dopiero w Chicago w 1933 r. Wystawę w Montrealu w 1967 r. zobaczyło ponad 50 mln widzów, a w Osace w 1970 r. frekwencja przekroczyła 64 mln osób. Kolejne wystawy światowe cieszyły się znacznie mniejszą popularnością. W Hanowerze w 2000 r. pojawiło się 18 mln zwiedzających, a w Aichi - pięć lat później - $22 \mathrm{mln}$. Dopiero znacznie więcej osób - $70 \mathrm{mln}$ - przyciągnęło chińskie Expo z 2010 roku. Pierwsze wystawy światowe zajmowały niewielką powierzchnię. W Londynie w 1851 r. wykorzystano obszar 11 ha, a w Paryżu w 1855 r. - 14 ha. Jednak już następna wystawa w stolicy Francji w 1867 r. obejmowała 87 ha. Kolejne wystawy były z reguły jeszcze większe: Wiedeń (1873) - 184 ha, St. Louis (1904) - 500 ha, Nowy Jork (1939) 493 ha. W drugiej połowie XX w. oraz w XXI w. wynajmowana powierzchnia zdecydowanie się zmniejszyła. Największe ekspozycje w tym okresie zorganizowano w: Sewilli (1992) - 215 ha, Hanowerze (2000) - 160 ha, Aichi (2005) - 173 ha. Wyjątkiem była ostatnia wystawa z 2010 r. w Szanghaju o powierzchni 582 ha $^{8}$.

Większość wystaw światowych okazała się deficytowa, a wiele goszczących je miast poniosło spore straty finansowe. Kiedy wydarzenie specjalistyczne zorganizowane w Nowym Orleanie w 1984 r. zbankrutowało, amerykański Kongres uchwalił, że w przyszłości takie przedsięwzięcia będą sponsorowane z środków prywatnych. W wielu krajach pawilony po Expo podupadły, a tereny po wystawach niszczeją. Dziesięć lat po wystawie zorganizowanej w Montrealu z 1967 r. Robert Altman wykorzystał jej pozostałości jako scenografię do kręcenia scen filmu Kwintet, z gatunku science fiction. Po ostatnim Expo 2010 również niewiele pozostało. Większość pawilonów - poza nielicznymi budynkami, w tym pawilonem gospodarzy (Chin) - została rozebrana.

Warto zauważyć, że przygotowaniom do wystaw światowych towarzyszą niekiedy spore kontrowersje. Przed szanghajską wystawą obrońcy praw człowieka zwracali uwagę na przymusowe wysiedlanie mieszkańców (ok. 60 tys. osób) z terenów przeznaczonych pod Expo, a także na brak odszkodowań i szykanowanie tych, którzy usiłowali się odwoływać i protestować. Zdarzą się również sytuacje, gdy kraje wycofują się z udziału w wystawach tuż przed ich rozpoczęciem. Taką decyzję podjęły władze Kuwejtu, Bhutanu oraz Burkina Faso w 2010 r.

\section{HISTORIA UDZIALU POLSKI W WYSTAWACH ŚWIATOWYCH}

Ze względu na brak państwowości, a także z przyczyn politycznych - przynależność do bloku socjalistycznego - historia udziału Polski w wystawach światowych nie jest bogata. Na początku organizowania wystaw przyjęto zasadę pozwalającą na prezentowa-

\footnotetext{
${ }^{8}$ Por. R. Giwalski, Sewilla i Expo'92, Wydawnictwo WRG, Warszawa 1992, s. 32-33, oraz http://www.bieparis.org (dostęp: 12.09.2014).
} 
nie własnych ekspozycji jedynie reprezentacjom państwowym. Następnie konsekwentnie przestrzegano tej reguły. Z tego względu do odzyskania suwerenności i powstania II Rzeczpospolitej polscy artyści oraz wytwórcy uczestniczyli w wystawach pod flagami innych narodów.

Nasz kraj po raz pierwszy zaprezentował samodzielnie swój dorobek w 1933 roku w Chicago. Był to skromny początek uczestnictwa Polski w wystawach światowych. W okresie międzywojennym udany dla Polski był wyjazd w 1937 roku do Paryża, gdzie zespół rodzimych wystawców otrzymał 78 nagród Grand Prix, a architektura pawilonu narodowego wyróżniona została jako jeden z trzech najlepszych obiektów ${ }^{9}$.

Po II wojnie światowej uwarunkowania polityczne przyczyniły się do absencji Polski podczas wielu wystaw światowych. Wynikało to z zimnowojennych napięć i z tego, że ówczesne Expo odbywały się poza krajami komunistycznymi - między innymi w Brukseli (1958), Montrealu (1967), Osace (1970). Ta sytuacja zmieniła się dopiero wraz z rozpoczęciem przemian w 1989 r. Po kilku dekadach przerwy Polska zaprezentowała się w 1992 r. w Sewilli, a pierwszy samodzielny pawilon wybudowała w Hanowerze w 2000 r.

Podczas ostatnich edycji wystaw światowych nasze narodowe pawilony, między innymi ze względu na ich oryginalne konstrukcje, należały do jednych z najchętniej odwiedzanych. Tak było podczas udziału Polski w Expo, które odbyły się w Hanowerze (2000), Aichi (2005) oraz Szanghaju (2010). W Niemczech polski pawilon o otwartych ścianach zbudowano w oparciu na stalowych słupach, na których podwieszona została konstrukcja ze stali, szkła oraz aluminium. Podczas wystawy zorganizowanej w Japonii elewację narodowego pawilonu wykonano $\mathrm{z}$ białej wikliny. $\mathrm{Z}$ kolei w Chinach budynek z polską ekspozycją przypominał z zewnątrz wielokrotnie zgiętą kartkę papieru (papierową ozdobę, zwaną potocznie wycinanka).

Należy zauważyć, że na udział naszego kraju w powszechnych wystawach światowych, wraz z każdą edycją przeznaczane były coraz większe środki finansowe. Na prezentację w Aichi w 2005 roku Polska wydała kwotę 34 mln zł, w Szanghaju w 2010 roku - 45 mln zł, zaś w 2015 roku ma przeznaczyć blisko $57 \mathrm{mln} \mathrm{z}^{10}$. Budżet wystąpienia, które odbędzie się podczas wystawy w Mediolanie, w znacznej części zasilony zostanie z środków programów Unii Europejskiej.

\section{EXPO 2010 - NAJWIĘKSZE WYDARZENIE WYSTAWIENNICZE W HISTORII}

Wystawa światowa w Szanghaju odbywała się 1 maja - 31 października 2010 roku pod hasłem „Lepsze miasto, lepsze życie” (Better City, Better Life). Oficjalny budżet wydarzenia to 4 mld USD, jednak przygotowanie infrastruktury pod Expo w całej aglomeracji mogło kosztować nawet 58 mld USD (jest to wyższa kwota niż ta, którą władze Chin wydały na organizację w Pekinie letnich igrzysk olimpijskich w 2008 r.) ${ }^{11}$. Tereny wystawowe zajmowały powierzchnię 528 ha nad rzeką Huangpu Jiang - po jej dwóch stronach - w dzielnicach Puxi oraz Pudong. Na tak dużym obszarze zlokalizowano pawilony, w których zaprezentowały się 192 państwa i 50 organizacji międzynarodowych

\footnotetext{
${ }^{9}$ W. Serwatowski, Expo - promocja globalna, „Aida Media” 8/51 (1998), s. 18; W. Świątek, Trzy polskie pawilony na wystawy światowe Expo, „Czasopismo Techniczne. Mechanika” 2012/26, s. 332.

${ }^{10}$ M. Grzegorczyk, Rzad zaprasza firmy na Expo 2015, „Puls Biznesu” 2014/61, s. 6.

11 M. Kruczkowska, Chiny chca przyćmić świat, http://wyborcza.pl/1,76842,7831680,Chiny_ chca_przycmic_swiat.html (dostęp: 15.09.2014).
} 
(w tym m.in. Czerwony Krzyż, ONZ). W ramach kompleksu funkcjonowało kilka linii autobusowych oraz linia metra. Ponadto w obrębie terenów wystawowych kursowały promy na 5 trasach. Według informacji udostępnionych przez organizatorów tereny szanghajskiego Expo w okresie 6 miesięcy zwiedziło ponad 73 mln osób, z czego 4,25 mln stanowili obcokrajowcy. Każdego dnia ekspozycje oglądało około 400 tys. osób ${ }^{12}$. Trzeba zaznaczyć, że są to szacunki podawane przez rząd chiński, któremu zależało na wysokiej frekwencji. Według zachodnich mediów, w celu zapewnienia dużej liczby zwiedzających, w wielu państwowych przedsiębiorstwach pracownicy otrzymali dzień wolny od pracy, aby móc uczestniczyć w wystawie ${ }^{13}$. Organizowane były także liczne wycieczki młodzieży szkolnej i studentów.

Zdecydowana większość budowli znajdujących się na terenach Expo 2010 charakteryzowała się oryginalnym wyglądem, gdyż to on w dużej mierze decydował o frekwencji osób zwiedzających ekspozycje znajdujące się wewnątrz pawilonów ${ }^{14}$. Osoba uczestnicząca jeden dzień w wystawie była w stanie zobaczyć zaledwie wystąpienia kilku państw. Wynikało to $\mathrm{z}$ rozległości terenów wystawowych oraz z długiego czasu oczekiwania w kolejkach, jakie ustawiały się przed ekspozycjami niemal wszystkich państw i organizacji (czas oczekiwania na wejście do najbardziej popularnych pawilonów wynosił nawet 4 godziny).

Niektóre budowle szczególnie silnie przyciagały uwage zwiedzających. W tym kontekście można przywołać kilka przykładów (rys. 1). Z elewacji brytyjskiego pawilonu wystawało 60 tys. przezroczystych prętów, zawierających włókna światłowodowe oraz nasiona 6 tys. gatunków roślin. Pręty poruszały się na wietrze i pozwalały dotrzeć do wnętrza obiektu światłu naturalnemu. Po zmierzchu iluminacja brytyjskiej ekspozycji wywoływała spektakularny efekt. Ekologiczny wymiar funkcjonowania pawilonu podkreślono w wypadku Szwecji: na obiekt składały się cztery prostopadłościany usytuowane w taki sposób, aby między nimi tworzyły się dwa, przecinające się pod kątem prostym, szczeliny. Elewację szwedzkiego budynku wyłożono estetyczną, ale również energooszczędną stalą, która umożliwiała odprowadzanie do wnętrza obiektu ciepło promieniowania słonecznego. Z kolei pawilon Arabii Saudyjskiej przybrał kształt półkuli, symbolizującej wiszącą łódź. Elementem ekspozycji był rozległy ekran o powierzchni boiska do piłki nożnej, a na dachu obiektu usypano z piasku wydmę oraz posadzono na niej 150 palm daktylowych, imitujących oazę. Z kolei na dachu futurystycznej bryły pawilonu Szwajcarii funkcjonował wyciąg krzesełkowy - stylizowany na alpejską kolejkę. Budynek z ekspozycją Singapuru z zewnątrz przypominał pozytywkę, a w jego wnętrzu znajdował się zbudowany z rozmysłem system pochylni, schodów, kratownic oraz platform. Zwieńczenie singapurskiego pawilonu stanowił ogród znajdujący się na dachu. Z ekspozycji Rosji wyłaniało się kilka wież w biało-złotej kolorystyce, przypominających architekturę charakterystyczną dla historycznych budynków tego kraju. Ażurowe zwieńczenie górnych

12 Shanghai World Expo Statistics, http://china.org.cn/travel/expo2010shanghai/2010-01/22/content_ 19288622.htm (dostęp: 15.09.2014); Facts and Statistics of World Expo 2010 Shanghai China, http://www.meet-in-shanghai.net/news_detail2010.php?id=1382 (dostęp: 15.09.2014).

${ }^{13}$ D. Barboza, Shanghai Expo Sets Record With 73 Million Visitors, „The New York Times”, 2 November 2010, http://www.nytimes.com/2010/11/03/world/asia/03shanghai.html?_r=2\&pagewanted=all\& (dostęp: 16.09.2014).

14 Wizualizacje wszystkich pawilonów można zobaczyć na oficjalnej stronie internetowej Expo 2010: http://en.expo.cn. Ponadto opisy ekspozycji narodowych, wraz z ich zdjęciami, znajdują się pod adresem: http://en.wikipedia.org/wiki/Expo_2010_pavilions. 
części wież było inspirowane ozdobami etnicznymi narodów zamieszkujących Rosję. Silnie z kulturą swojego kraju kojarzył się również pawilon Malezji, który symbolizował Rumah Gadang - tradycyjny dom ludu Minangkabau. Uwagę osób zwiedzających Expo 2010 przykuwał wielobarwny dach malezyjskiego obiektu, udekorowany techniką malarską Batik. Jednak największym budynkiem na Expo 2010, o powierzchni 160 tys. $\mathrm{m}^{2}$ i wysokim na ponad $60 \mathrm{~m}$, był pawilon gospodarzy. Ulokowany centralnie obiekt nazwano „Orientalną koroną”. Pawilon, w różnych odcieniach czerwieni, miał kształt odwróconego stożka i przypominał starożytną chińską koronę. Forma budynku odzwierciedlała dougong, czyli tradycyjny element, spotykany od ponad 2,5 tys. lat w azjatyckiej architekturze.

Rys. 1. Wybrane pawilony podczas Expo 2010 (Chin, Malezji, Rosji, Singapuru, Szwajcarii, Szwecji)
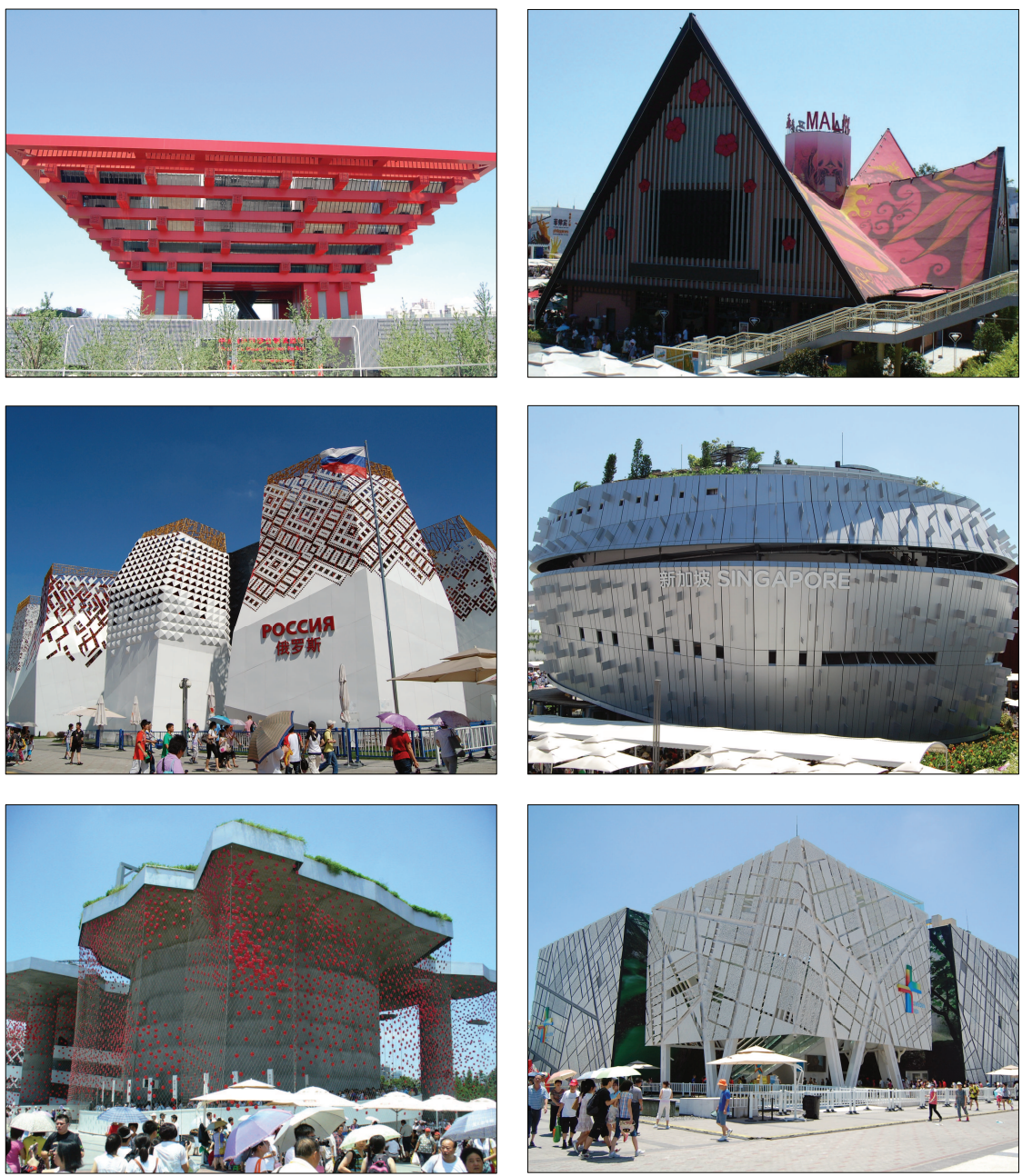

Źródło: fotografie własne. 
Intersujące inscenizacje zaaranżowano we wnętrzach wielu pawilonów. Na przykład w ramach prezentacji Danii można było oglądać basen z oryginalnym (przetransportowanym specjalnie na Expo z Kopenhagi) pomnikiem Małej Syrenki. Duńską ekspozycję zwiedzający mogli oglądać, jeżdżąc na rowerach. Francja pokazała dzieła wybitnych europejskich artystów (6 obrazów i 1 rzeźbę), w tym między innymi van Gogha, Édouarda Maneta i Paula Gauguina. Główną atrakcją łotewskiej ekspozycji był pionowy tunel aerodynamiczny, w którym odbywały się pokazy z udziałem dwóch zawodowych pilotów. Wśród publiczności przeprowadzano natomiast losowania - wygraną była możliwość samodzielnego odbycia lotu $\mathrm{w}$ tunelu. W centralnym punkcie niemieckiego pawilonu znajdowała się kula (o średnicy $3 \mathrm{~m}$ ) pokryta diodami LED, za której pomocą przeprowadzano widowiskowe pokazy. Podczas ich trwania zwiedzający mogli zobaczyć obrazy dotyczące historii Niemiec oraz czasów współczesnych. Kula uruchamiała się automatycznie za pomocą czujnika dźwięku, gdy we wnętrzu obiektu zgromadziło się wystarczająco dużo osób. Z kolei w pawilonie Belgii można było zakupić oryginalne słodycze (czekoladki, lody, wafle), z których słynie ten kraj.

\section{PREZENTACJA POLSKI NA EXPO 2010 W SZANGHAJU}

Instytucjami odpowiedzialnymi za przygotowanie wystapienia podczas Expo 2010 były Polska Agencja Rozwoju Przedsiębiorczości oraz Polska Agencja Informacji i Inwestycji Zagranicznych. Głównym celem ekspozycji narodowej miało być przedstawienie naszego kraju jako miejsca o dużym potencjale, młodego, nowoczesnego społeczeństwa i dynamicznie rozwijającego się członka Unii Europejskiej. Pośrednio obecność na Expo miała się przyczynić do zwiększenia napływu bezpośrednich inwestycji kapitału chińskiego oraz rozwoju współpracy gospodarczej i kulturalnej. Kierunki kreowania spójnego wizerunku Polski jako kraju pozytywnych przemian zawarte zostały w dokumencie Koncepcja programowa uczestnictwa Polski w Światowej Wystawie Expo 2010, Szanghaj, Chiny, który w maju 2008 r. przyjęła Rada Ministrów ${ }^{15}$.

Polska ekspozycja prezentowana była w pawilonie o oryginalnej bryle (rys. 2). Elewacja budynku nawiązywała do tradycyjnej, ludowej wycinanki (w nocy podświetlona elewacja przypominała wzorzysty lampion). Obiekt, osadzony na planie prostokąta (o wymiarach $20 \times 50 \mathrm{~m}$ ), przypominał ażurowe pudełko. Taka aranżacja była bliska chińskiej estetyce, gdyż w kulturze Państwa Środka tworzenie papierowych ozdób znane jest od wieków. Intrygujący dla Chińczyków wygląd przyczynił się do dużego zainteresowania ekspozycją - oszacowano, że każdego dnia zwiedziło ją około 45 tys. osób. W sumie liczba osób, które odwiedziły polską ekspozycję w ciągu 6 miesięcy trwania wystawy, przekroczyła $8,2 \mathrm{mln}^{16}$.

Polski pawilon, dzięki oryginalnemu wyglądowi, stał się jednym z najbardziej rozpoznawanych symboli Expo 2010. Jego zdjęcie pojawiało się na plakatach promujących wystawę (wśród kilku innych wybranych ekspozycji). Wizerunek pawilonu można było również zobaczyć w prasie i innych mediach. Po zakończeniu wystawy obiekt został nagrodzony srebrnym medalem za najbardziej kreatywną prezentację (pierwsze miejsce przypadło pawilonowi Szwecji).

\footnotetext{
${ }^{15}$ Polska na Expo 2010 w Szanghaju, „Brief for Poland”, dodatek do „Brief” 5/104 (2008), s. 92.

16 W. Rogacin, Ponad $8 \mathrm{mln}$ Chinczyków odwiedzito polski pawilon na Expo $w$ Szanghaju, http://www.polskatimes.pl/artykul/332800,ponad-8-mln-chinczykow-odwiedzilo-polski-pawilon-na-expo-wszanghaju,id,t.html?cookie=1 (dostęp: 18.09.2014).
} 
Rys. 2. Pawilon Polski podczas Expo 2010
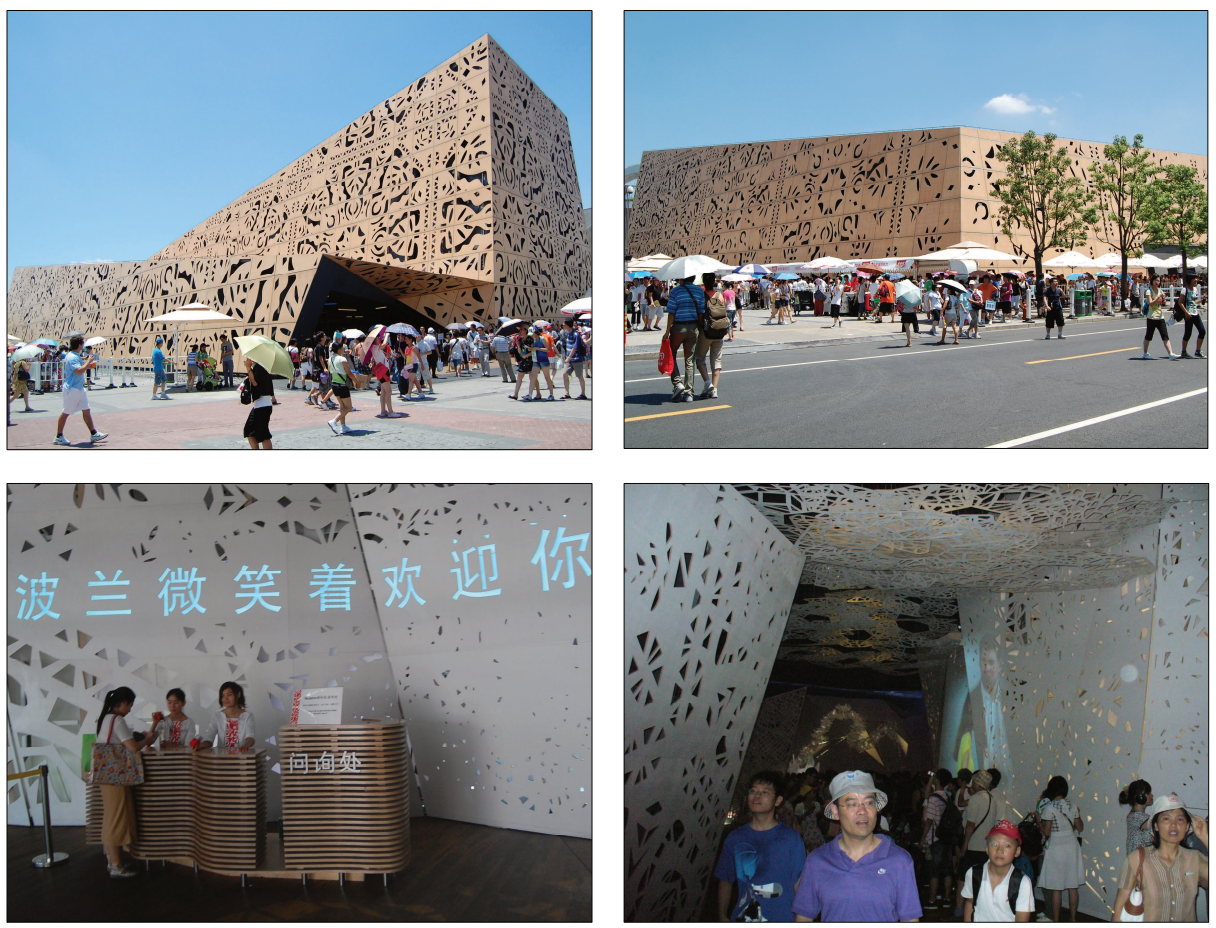

Źródło: fotografie własne.

Przy wejściu do pawilonu znajdowała się strefa informacyjna. W jej obrębie zwiedzających witały chińskie hostessy, ubrane w stroje z naniesioną symboliką odwołującą do „wycinanek” z elewacji. Dalej, idąc korytarzem, w ażurowych ścianach można było zobaczyć zainstalowane monitory, na których wyświetlano prezentacje dotyczące naszego kraju. W kolejnej części obiektu znajdowała się audytoryjna sala do wyświetlania prezentacji na dużym ekranie, a zaraz za nią - wydzielona część restauracyjna, w której serwowano dania z Polski (m.in. bigos, pierogi, gołąbki, żeberka, golonkę, tatara), a także polskie alkohole. W pawilonie znajdował się również sklep, w którym można było nabyć wyroby jubilerskie z bursztynu. Na piętrze zlokalizowano galerię plakatu oraz wystawę rodzimych wynalazków. Dużym zainteresowaniem wśród zwiedzających cieszył się pokaz trójwymiarowego filmu Historia Polski, który można było zobaczyć w wydzielonej sali. Ta ośmiominutowa animacja stworzona została na potrzeby Expo przez Tomasza Bagińskiego - reżysera nominowanego w przeszłości do Oscara.

W prasie, jak również literaturze dotyczącej wystawiennictwa wygląd polskiego pawilonu oceniono pozytywnie, twierdząc między innymi, że ,spełnił on pokładane w nim oczekiwania, gdyż będąc spójnym z językiem komunikacji naszych czasów, skutecznie zaznaczył się w świadomości osób zwiedzających Expo". Pojawiły się jednak negatywne opinie dotyczące ekspozycji prezentowanej wewnątrz budynku. Zauważono, że „merytoryczno-formalna część prezentacji i wyposażenia postrzegana była za banalną, a jej oddziaływanie na Chińczyków trudne do przewidzenia. Szczególnie drażniący był fakt cał- 
kowitego rozejścia się ekscytującej i nowoczesnej formy pawilonu z banalną prezentacją audiowizualną" 17 .

Oprócz wyglądu pawilonu oraz atrakcyjności samej ekspozycji kluczowy dla rezultatów uzyskiwanych podczas Expo jest program imprez towarzyszących. W ramach polskiego wystapienia zrealizowany został program kilkudziesięciu wydarzeń kulturalnych oraz gospodarczych. Wydarzenia te odbywały się głównie w pierwszych miesiącach wystawy. Na program wydarzeń kulturalnych złożyły się koncerty muzyczne, występy taneczne, wystawy fotograficzne oraz pokazy filmowe. Wśród imprez o charakterze ekonomicznym znalazły się przede wszystkim misje gospodarcze (m.in. Związku Banków Polskich, sektora IT, branży ochrony środowiska) oraz akcje promocyjne wybranych miast i regionów (Lublina, Kielc, Szczecina; województw: śląskiego, małopolskiego, mazowieckiego). Najważniejszym punktem programu wystąienia narodowego był „Dzień Polski”, który odbył się 22 maja. W tym dniu zorganizowano kilka wydarzeń o charakterze kulturalnym, a ekspozycję odwiedziła delegacja polskiego rządu, której przewodniczył minister kultury i dziedzictwa narodowego.

Dokładne określenie efektów, jakie przyniósł udział w wystawie światowej z 2010 roku, nie jest możliwe. Większość uzyskanych efektów miała charakter wizerunkowy, co miało się przełożyć na zwiększone zainteresowanie Polską wśród turystów i inwestorów. Polska Agencja Informacji i Inwestycji Zagranicznych, podsumowując aktywność rodzimego pawilonu podczas Expo 2010, wskazała na istotny wpływ wystapienia na postrzeganie naszego kraju przez obywateli Państwa Środka ${ }^{18}$. W prasie można było jednak znaleźć komentarze podające w wątpliwość osiągnięte rezultaty wizerunkowe. Po szanghajskiej wystawie przeprowadzono badanie wśród przedsiębiorców z tego miasta - większość z nich nie wiedziała, że Polska miała swój pawilon ${ }^{19}$.

Organizator wystapienia na Expo 2010 podał, że w seminariach i prezentacjach gospodarczych organizowanych w polskim pawilonie wzięło udział około tysiąc przedstawicieli chińskich zrzeszeń gospodarczych i firm z Szanghaju oraz prowincji regionu Delty Rzeki Jangcy. W spotkaniach z lokalnymi podmiotami uczestniczyło ponad 120 polskich firm. W pawilonie narodowym pojawiło się również 1,2 tys. dziennikarzy reprezentujących chińskie media ${ }^{20}$. Jako efekt uczestnictwa w wystawie uznaje się podpisanie w listopadzie 2010 r. w Warszawie na szczeblu rządowym deklaracji o współpracy gospodarczej między Polską i Chinami. Oprócz tej deklaracji podpisano także kilka umów ważnych dla rodzimych przedsiębiorstw.

\section{PODSUMOWANIE}

Przez dziesięciolecia wystawy światowe zmieniały swoją formułę, dostosowując się do uwarunkowań gospodarczych, społecznych i politycznych. Obecnie tematyka Expo dotyczy przede wszystkim problemów współczesnej cywilizacji. Nad ich niegdyś ważną

\footnotetext{
${ }^{17}$ W. Świątek, op. cit., s. 337, 339.

${ }^{18}$ Por. między innymi J. Dworzycki, Sukces Polski na EXPO 2010 w Szanghaju, http://www.mg.gov.pl/ node/11991 (dostęp: 19.09.2014); Gratulacje za Expo, http://www.paiz.gov.pl/20110131/gratulacje_za_expo (dostęp: 19.09.2014).

${ }^{19}$ M. Grzegorczyk, Polska znowu odpuszcza Expo, http://www.pb.pl/3146012,66881,polska-znowu-odpuszczaexpo (dostęp: 20.09.2014).

${ }^{20}$ Podsumowanie udziału Polski w Expo 2010 w Szanghaju, http://www.expo2010.com.pl/\#/pl/news/ badceb3b4d16f636d34105d8d582329f (dostęp: 19.09.2014).
} 
funkcją propagandowo-edukacyjną zaczęła dominować funkcja marketingowa, związana z kreowaniem wizerunku prezentujących się państw. Jednak wraz z nastaniem wielokanałowej komunikacji, dokonującej się w skali globalnej, oraz w świetle wzrostu kosztów prowadzenia aktywności wystawienniczej coraz częściej podawana jest w wątpliwość zasadność uczestniczenia w Expo. Aby odnieść się do tych wątpliwości, warto zestawić przesłanki przemawiające na korzyść takiej aktywności oraz przeciw niej.

$\mathrm{Na}$ podstawie analizy trendów występujących w wystawiennictwie oraz wniosków wynikających z obserwacji poczynionych podczas Expo 2010 można zidentyfikować argumenty, które przemawiają przeciw prezentowaniu się w ramach Expo. W tym kontekście należy wskazać na to, że:

- konieczne jest ponoszenie przez wystawiające się kraje wysokich kosztów przygotowania pawilonów oraz obsługi ekspozycji w trakcie kilku miesięcy trwania wydarzenia;

- w wielu krajach wysuwane są zarzuty dotyczące pokrywania ze środków publicznych kosztów uczestniczenia w Expo;

- występują spore trudności z pozyskaniem sponsorów dla narodowych ekspozycji;

- wystawy zatraciły swój dawny konkursowy charakter, zatem nie występuje element bezpośredniej rywalizacji między państwami;

- w dobie powszechnego dostępu do globalnej sieci komputerowej poszczególne kraje zyskały możliwość szerokiego zaprezentowania się w internecie;

- trudno określić efekty marketingowe, które wynikają z obecnością danego kraju na Expo;

- obserwowane jest stosunkowo niewielkie (pod względem narodowości) zróżnicowanie publiczności zwiedzającej ekspozycje - najliczniejszą grupę zwiedzających stanowią mieszkańcy kraju goszczącego wystawę, natomiast przyjeżdża niewielu zagranicznych turystów.

Analiza formuły obecnych wystaw światowych pozwala także na sprecyzowanie następujących przesłanek, wskazujących na potrzebę uczestniczenia w Expo poszczególnych państw:

- tworzy się okazja do zapoznania się z prezentacjami wielu krajów w jednym miejscu oraz możliwość poznania wielu kultur przez osoby (przede wszystkim mieszkańców kraju goszczącego wystawę), dla których świat zewnętrzny dotychczas był niedostępny;

- pojawia się możliwość zaprezentowania państw, które na co dzień pozostają w izolacji międzynarodowej (tak jak m.in. w wypadku Iranu oraz Korei Północnej podczas wystawy w Szanghaju);

- dzięki bezpośrednim spotkaniom każdy wystawiający się kraj może się zaprezentować przez oddziaływanie na wszystkie zmysły zwiedzających (w wypadku mediów elektronicznych można oddziaływać tylko poprzez wzrok i słuch);

- obecność na Expo sprzyja organizowaniu misji gospodarczych oraz zapraszaniu przedstawicieli zagranicznych środowisk biznesowych do odwiedzenia pawilonu i przeprowadzenia rozmów;

- często po wystawach światowych powstają obiekty architektoniczne urastające do rangi symbolu miejsc goszczących wydarzenie, które są rozpoznawane na całym świecie i przyciągają turystów (np. Wieża Eiffla w Paryżu, Most Vasco da Gamy w Lizbonie); 
- stworzenie możliwości zaprezentowania się nie tylko krajom, ale również miastom i regionom (w ramach wystąpień narodowych), których na co dzień nie stać na prowadzenie aktywności promocyjnej w skali globalnej.

Prowadzenie skutecznej aktywności marketingowej podczas Expo w dużej mierze determinowane jest dostępnymi przez poszczególne kraje budżetami, gdyż przygotowanie interesujących, oryginalnych wystapień wymaga poniesienia sporych nakładów finansowych. Koszty generuje nie tylko wybudowanie i wyposażenie pawilonów, ale również kosztowne są między innymi usługi logistyczne, wynagrodzenie krajowego oraz miejscowego personelu, prowadzenie działań promocyjnych. Udział Polski w Expo 2010 kosztował $45 \mathrm{mln}$ zł. Pozyskanie jednak takiej kwoty ze środków publicznych sprawiło spore problemy - mimo że budżet wystąienia jeszcze przed rozpoczęciem wystawy został znacznie zredukowany (pierwotnie miał on wynosić $120 \mathrm{mln}$ zł). Problemy finansowe również wystąpiły podczas trwania Expo - prasa wówczas informowała, że już w czerwcu zabrakło pieniędzy na utrzymywanie personelu do obsługi rozbudowanego programu misji gospodarczych, spotkań biznesowych oraz wydarzeń kulturalnych ${ }^{21}$. W odniesieniu do kolejnej wystawy światowej, która odbędzie się w Mediolanie, w mediach pojawiły się informacje, że ze względu na wysokie koszty ekspozycji, Polska zrezygnuje z wystąpienia $^{22}$. Ostatecznie jednak pawilon naszego kraju będzie funkcjonował we Włoszech w 2015 roku.

Wystawa, która odbyła się w Szanghaju, była największym w historii - pod wieloma względami - wydarzeniem wystawienniczym. Wśród uczestników znalazło się 192 wystawców, w tym: 186 państw uznawanych przez ONZ, 2 narody nieuznawane przez tę organizację (Tajwan i Palestyna), 2 terytoria stowarzyszone Nowej Zelandii (Wyspy Cooka i Niue), 2 specjalne regiony administracyjne Chińskiej Republiki Ludowej (Hongkong i Makau). Trudno sobie zatem wyobrazić, aby w tak szerokiej grupie wystawców Expo 2010 zabrakło Polski. Odnosząc się jednak do kolejnych wystaw światowych i uwzględniając argumenty przemawiające zarówno za, jak i przeciw prowadzeniu podczas ich trwania aktywności marketingowej, należy uznać formułę Expo za anachroniczną, oferującą korzyści nieadekwatne do ponoszonych nakładów. Do rozważenia pozostaje kwestia zmiany charakteru wystąpienia narodowego i uczestniczenia z zaangażowaniem znacznie mniejszych środków finansowych - bez budowania własnego pawilonu, w ramach wystąpień kolektywnych. W niedalekiej przyszłości należy się zatem spodziewać, że coraz więcej państw, w tym również nasz kraj, będzie rezygnowało z samodzielnego uczestniczenia w wystawach światowych. Już w 2015 r. w Mediolanie zaprezentuje się o wiele mniej wystawców niż w Szanghaju. We włoskiej wystawie będzie uczestniczyło niespełna 150 państw (zabraknie ekspozycji m.in. Norwegii, Szwecji, Finlandii, Danii, Islandii, Holandii, Portugalii, Kanady, Australii, Republiki Południowej Afryki). Być może także polskiej ekspozycji zwiedzający nie zobaczą już podczas wystawy Expo 2020, która odbędzie się w Dubaju.

\footnotetext{
${ }^{21}$ Expo 2010: Polska ekspozycja w Szanghaju wpadta w ktopoty finansowe, http://forsal.pl/artykuly/429368, expo_2010_polska_ekspozycja_w_szanghaju_wpadla_w_klopoty_finansowe.html (dostep: 20.09.2014).

${ }^{22}$ M. Grzegorczyk, op. cit.
} 


\section{LITERATURA}

[1] Barboza D., Shanghai Expo Sets Record With 73 Million Visitors, „The New York Times”, 2 November 2010, http://www.nytimes.com/2010/11/03/world/asia/03shanghai.html?_r=2\& pagewanted=all\& (dostęp: 16.09.2014).

[2] Deng Y., Poon S.W., Expo 2010 Shanghai China: a signature chapter of the Huangpu Riverfronts Trilogy, ,Journal of Place Management and Development” 5/2 (2012).

[3] Dornscheidt W.M., Groth C., Reinhard H.W., Mega-events, [w:] Trade Show Management, red. M. Kirchgeorg, W.M. Dornscheidt, W. Giese, N. Stoeck, Gabler, Wiesbaden 2005.

[4] Drexlerowa A.M., Olszewski A.K., Polska i Polacy na powszechnych wystawach światowych 1851-2000, Instytut Sztuki PAN, Warszawa 2005.

[5] Dworzycki J., Sukces Polski na EXPO 2010 w Szanghaju, http://www.mg.gov.pl/ node/11991 (dostęp: 19.09.2014).

[6] Expo 2010: Polska ekspozycja w Szanghaju wpadta $w$ ktopoty finansowe, http://forsal.pl/artykuly/429368,expo_2010_polska_ekspozycja_w_szanghaju_wpadla_w_klop oty_finansowe.html (20.09.2014).

[7] Facts and Statistics of World Expo 2010 Shanghai China, http://www.meet-inshanghai.net/news_detail2010.php?id=1382 (dostęp: 15.09.2014).

[8] Giwalski R., Sewilla i Expo'92, WRG, Warszawa 1992.

[9] Gratulacje za Expo, http://www.paiz.gov.p1/20110131/gratulacje_za_expo (dostęp: 19.09.2014).

[10] Grzegorczyk M., Polska znowu odpuszcza Expo, http://www.pb.pl/3146012,66881, polskaznowu-odpuszcza-expo (dostęp: 20.09.2014).

[11] Grzegorczyk M., Rzqd zaprasza firmy na Expo 2015, „Puls Biznesu” 2014/61.

[12] Kruczkowska M., Chiny chcq przyćmić świat, http://wyborcza.pl/1,76842,7831680, Chiny_chca_przycmic_swiat.html (dostęp: 15.09.2014).

[13] Locker P., Exhibition Design, AVA Publishing, Lausanne 2011.

[14] Podsumowanie udziatu Polski w Expo 2010 w Szanghaju, http://www.expo2010.com.pl/\#/ $\mathrm{pl} /$ news/badceb3b4d16f636d34105d8d582329f (dostęp: 19.09.2014).

[15] Polska na Expo 2010 w Szanghaju, „Brief for Poland”, dodatek do „Brief” 5/104 (2008).

[16] Roche M., Mega-events and Modernity: Olympics and Expos in the Growth of Global Culture, Routledge, London 2000.

[17] Rogacin W., Ponad $8 \mathrm{mln}$ Chińczyków odwiedziło polski pawilon na Expo w Szanghaju, http://www.polskatimes.pl/artykul/332800,ponad-8-mln-chinczykow-odwiedzilo-polskipawilon-na-expo-w-szanghaju,id,t.html?cookie=1 (dostęp: 18.09.2014).

[18] Serwatowski W., Expo - promocja globalna, „Aida Media” 8/51 (1998).

[19] Shanghai World Expo Statistics, http://china.org.cn/travel/expo2010shanghai/201001/22/content_19288622.htm (dostęp: 15.09.2014).

[20] Świątek W., Trzy polskie pawilony na wystawy światowe Expo, „Czasopismo Techniczne. Mechanika" 2012/26.

[21] World Expos, http://www.bie-paris.org/site/en/expos/about-expos/expo-categories/worldexpos (dostęp: 12.09.2014).

[22] Yu L., Wang Ch., Seo J., Mega event and destination brand: 2010 Shanghai Expo, „International Journal of Event and Festival Management" 3/1 (2012).

\section{AN EVALUATION OF THE REASON FOR PARTICIPATING IN WORLD EXPOSITIONS (IN THE CONTEXT OF THE EXHIBITION ACTIVITY OF POLAND DURING EXPO 2010 IN SHANGHAI)}

Nowadays universal expositions (Expo) are held every five years and enable almost all countries and several dozens of international organisations to exhibit themselves. Participat- 
ing in such events is believed to contribute mostly to creating a desired national brand. However, the participation in a six-month Expo event is considered a great organisational challenge and means heavy expenditures to be incurred by national budgets. Furthermore, owing to the development of the Internet, billions of people have nowadays an easy access to the information about individual countries and their offers. Therefore, the reason for organising such huge events (also referred to as mega-events) like world expositions in the $21^{\text {st }}$ century can be questioned. One may advance a thesis that the primary function of those expositions, i.e. informative and educational, which has been served for the last 150 years, is now of marginal importance. And thus, the aim of this article is to evaluate the reason for exhibiting during world expositions. To attain the aforementioned goal, there have been gathered the arguments for participating in such events (such as an opportunity to get the knowledge about the exhibition performances of many countries in one place, the presentation of national offers engaging all visitors' senses), as well as counterarguments (high participation costs, the decline of contest nature, difficulty in defining achieved image-related effects). The author's conclusions result from a many years' observation of the trade show and economic exhibition market, as well as from the observation made during Expo 2010, which was held in Shanghai.

Keywords: world exposition, Expo 2010, exhibit marketing, country image.

\section{DOI: 10.7862/rz.2014.mmr.47}

Tekst złożono w redakcji: listopad 2014

Przyjęto do druku: grudzień 2014 